\title{
Mitochondrial Damage
}

National Cancer Institute

\section{Source}

National Cancer Institute. Mitochondrial Damage. NCI Thesaurus. Code C45524.

Mitochondrial Damage involves any process that leads to dysfunction of mitochondria, whether by oxidative damage, mutation of mitochondrial DNA or other by means. 